\title{
Actions of the Judicial Commission of the International Committee on Systematic Bacteriology on Requests for Opinions Published Between July 1979 and April 1981
}

\author{
LAWRENCE G. WAYNE \\ Chairman, Judicial Commission, International Committee on Systematic Bacteriology, Veterans \\ Administration Medical Center, Long Beach, California 90822
}

This report covers those requests for an Opinion that were published between July 1979 and April 1981 upon which a vote has been taken. Occasional status reports will be published identifying requests that have been resolved.

The Statutes of the International Committee on Systematic Bacteriology (ICSB), which are printed in the Bacteriological Code (10), provide for formal publication of Opinions that have been issued by the Judicial Commission of the ICSB. There is, however, no provision for formal publication of denials of Opinions that have been requested, other than as minutes of the meetings of the Judicial Commission. Since some requests are resolved by mail ballots, there may be a period of several years when a request may appear to be pending, yet have been already resolved. To minimize this period of uncertainty, occasional status reports will be published, identifying those requests that have already been resolved, either affirmatively or negatively. The following report covers those requests published between the 1978 and 1982 meetings of the Judicial Commission upon which a vote has been taken. (It should be noted that the minutes of the 1982 meeting of the ICSB will record that Statute article 8a (5) has been amended to provide a waiting period of 12 months, instead of 6 months, between the date of publication of a request and submission of the request to the Judicial Commission for vote.)

Nomenclature of Enterobacteriaceae. Lapage (9) requested that the name Enterobacteraceae be substituted for the family name Enterobacteriaceae, and that Enterobacter be substituted for Escherichia as the type genus. At its meeting on 6 August 1982, the Judicial Commission denied this request and noted that a request by Goodfellow and Trüper to substitute the name Escherichiaceae for the family name Enterobacteriaceae had recently been published (4) and is still pending. The Judicial Commission had previously indicated (8) that Enterobacteriaceae retained its standing in spite of its displacement to a footnote in the Approved Lists (12) and remains the valid name for the family, as does Escherichia as the type genus, unless and until other action is taken.
Neotype strain of Microcyclus aquaticus. Larkin and Borrall (11) proposed ATCC 25396 as the neotype strain of $M$. aquaticus Ørskov 1928. This strain appears as the type in the Approved Lists (12), so no formal Opinion need be published.

Type species of the genus Flavobacterium. Holmes and Owen (7) reported that the type strain of $F$. aquatile, ATCC 11947, which appears to be the only recognized strain of the species, is not derived from the original strain that bore the epithet aquatile and does not conform adequately to the original description. They therefore proposed rejection of $F$. aquatile as a nomen dubium and proposed substitution of $F$. breve, which does not appear in the Approved Lists (12), as the type species. ATCC 11947 appears as the type strain of $F$. aquatile in the Approved Lists, and the Commission could find no great potential for confusion in retaining $F$. aquatile, nor a strong basis in the Bacteriological Code (10) for rejecting it, and so the requested Opinion was denied.

Neotype strains for seven Bacteroides species. Cato et al. (2) proposed neotype strains for $B$. capillosus ATCC 29799, B. coagulans ATCC $29798, B$. pneumosintes ATCC 33048, B. furcosus ATCC 25662, B. putredinis ATCC $29800, B$. nodosus ATCC 25549 , and $B$. praecutus ATCC 25539. All of these strains appear as the types of the respective species in the Approved Lists (12), so no formal Opinion need be published.

Conservation of Serratia liquefaciens over $S$. proteamaculans. Holmes (6) noted that S. proteamaculans, an uncommonly used name, threatened the frequently used name $S$. liquefaciens as a possible senior subjective synonym, and he requested conservation of $S$. liquefaciens over $S$. proteamaculans. Subsequently Grimont et al. (5) provided evidence that the two species are not synonymous, so the requested Opinion was considered inappropriate and was denied.

Type species of Spirochaeta. Canale-Parola (1) 
noted that no culture exists of $S$. plicatilis, the type species of the genus Spirochaeta, and proposed that $S$. stenostrepta replace it as the type species. The Judicial Commission received arguments that $S$. plicatilis does exist in nature, and would probably some day be cultivated. If it were markedly different from $S$. stenostrepta, an awkward situation would arise wherein the species that gave birth to the genus (and order) might be displaced from that genus. Rule 18a of the Bacteriological Code (10) does permit a description to serve in place of a type culture for a taxon that has not yet been cultivated in the laboratory. Therefore the Judicial Commission voted to deny the requested Opinion.

Type species of Eubacterium. Cato et al. (3), noting that the genus Eubacterium Prévot is included in the Approved Lists (12) with $E$. foedans shown as the type species but that $E$. foedans itself does not appear as a valid species in the Approved Lists, proposed that E. limosum (Eggerth) Prévot be designated as the type species. The Judicial Commission voted to approve this proposal, and a formal Opinion designating $E$. limosum as the type species will be published shortly.

\section{LITERATURE CITED}

1. Canale-Parola, E. 1981. Proposal that Spirochaeta stenostrepta Zuelzer replace Spirochaeta plicatilis Ehrenberg as the type species of the genus Spirochaeta Ehrenberg. Request for an Opinion. Int. J. Syst. Bacteriol. 31:105106.

2. Cato, E. P., L. V. Holdeman, and W. E. C. Moore. 1979. Proposal of neotype strains for seven non-saccharolytic Bacteroides species. Int. J. Syst. Bacteriol. 29:427-434.
3. Cato, E. P., L. V. Holdeman, and W. E. C. Moore. 1981. Designation of Eubacterium limosum (Eggerth) Prévot as the type species of Eubacterium. Request for an Opinion. Int. J. Syst. Bacteriol, 31:209-210.

4. Goodfellow, M., and H. G. Trüper. 1982. Escherichiaceae nom. nov., a name to replace Enterobacteriaceae. Request for an Opinion. Int. J. Syst. Bacteriol. 32:383.

5. Grimont, P. A. D., F. Grimont, and M. P. Starr. 1981. Comment on a request to the Judicial Commission to conserve the specific epithet liquefaciens over the specific epithet proteamaculans in the name of the organism currently known as Serratia liquefaciens. Int. J. Syst. Bacteriol. 31:211-212.

6. Holmes, B. 1980. Proposal to conserve the specific epithet liquefaciens over the specific epithet proteamaculans in the name of the organism currently known as Serratia liquefaciens (Grimes and Hennerty 1931) Bascomb et al. 1971. Int. J. Syst. Bacteriol. 30:220-222.

7. Holmes, B., and R. J. Owen. 1979. Proposal that Flavobacterium breve be substituted as the type species of the genus in place of Flavobacterium aquatile and emended description of the genus Flavobacterium: status of the named species of Flavobacterium. Int. J. Syst. Bacteriol. 29:416-426.

8. Judicial Commission of the International Committee on Systematic Bacteriology. 1981. Present standing of the family name Enterobacteriaceae Rahn 1937. Int. J. Syst. Bacteriol. 31:104.

9. Lapage, S. P. 1979. Proposal of Enterobacteraceae nom. nov. as a substitute for the illegitimate but conserved name Enterobacteriaceae Rahn 1937. Request for an Opinion. 1979. Int. J. Syst. Bacteriol. 29:265-266.

10. Lapage, S. P., P. H. A. Sneath, E. F. Lessel, V. B. D. Skerman, H. P. R. Seeliger, and W. A. Clark (ed). 1975. International code of nomenclature of bacteria, 1975 revision. American Society for Microbiology, Washington, D.C.

11. Larkin, J. M., and R. Borrall. 1979. Proposal of ATCC 25396 as the neotype strain of Microcyclus aquaticus Ørskov 1928. Int. J. Syst. Bacteriol. 29:414-415.

12. Skerman, V. B. D., V. McGowan, and P. H. A. Sneath (ed). 1980. Approved lists of bacterial names. Int. J. Syst. Bacteriol. 30:225-420. 